\title{
Isolation of Lentibacillus salicampi strains and Lentibacillus juripiscarius sp. nov. from fish sauce in Thailand
}

\author{
Sirilak Namwong, ${ }^{1}$ Somboon Tanasupawat, ${ }^{1}$ Thitapha Smitinont, ${ }^{2}$ \\ Wonnop Visessanguan, ${ }^{2}$ Takuji Kudo ${ }^{3}$ and Takashi Itoh ${ }^{3}$ \\ ${ }^{1}$ Department of Microbiology, Faculty of Pharmaceutical Sciences, Chulalongkorn University, \\ 254 Phayathai Road, Wangmai, Pathumwan, Bangkok 10330, Thailand
}

Correspondence

Somboon Tanasupawat

Somboon.T@chula.ac.th

\author{
${ }^{2}$ National Center for Genetic Engineering and Biotechnology, National Science and Technology \\ Development Agency, 113 Thailand 12 Science Park, Phaholyothin Road, Klong 1, Klong \\ Luang, Pathumthani 12120, Thailand \\ ${ }^{3}$ Japan Collection of Microorganisms, RIKEN BioResource Center, 2-1 Hirosawa, Wako-shi, \\ Saitama 351-0198, Japan
}

\begin{abstract}
Eight strains of aerobic, spore-forming, Gram-positive, moderately halophilic bacteria were isolated from sauce (nam-pla and bu-du) produced in Thailand by the fermentation of fish. They grew optimally in the presence of $10 \% \mathrm{NaCl}$, at $37^{\circ} \mathrm{C}$ and $\mathrm{pH} 7 \cdot 0$. A diagnostic diamino acid, meso-diaminopimelic acid, was present in the cell-wall peptidoglycan. The predominant menaquinone was MK-7. The major cellular fatty acids were anteiso- $C_{15: 0}$ and iso- $C_{16: 0}$. Phosphatidylglycerol, diphosphatidylglycerol and an unidentified glycolipid were found to be the major polar lipid components. The DNA G+C content was $42-43 \mathrm{~mol} \%$. These bacteria were further divided into two groups based on phenotypic characteristics and DNA-DNA similarities. Three strains of Group I were highly affiliated to the type strain of Lentibacillus salicampi in terms of phenotypic characterization and DNA-DNA similarities (96-102\%); accordingly, they were identified as strains of $L$. salicampi. A representative strain of Group II, strain IS40-3 ${ }^{\top}$, was most closely related to $L$. salicampi in terms of $16 \mathrm{~S}$ rRNA-based phylogenetic analysis, although five strains of Group II could be distinguished from L. salicampi by means of several phenotypic properties, low $16 \mathrm{~S}$ rRNA gene sequence similarity $(95 \cdot 2 \%)$ and low DNA-DNA similarities (12-32\%). Therefore, the Group II strains should be included in a novel species of the genus Lentibacillus, for which the name Lentibacillus juripiscarius sp. nov. is proposed. The type strain is IS40-3 ${ }^{\top}\left(=\mathrm{JCM} 12147^{\top}=\right.$ PCU $229^{\top}=$ TISTR $\left.1535^{\top}\right)$.
\end{abstract}

Nam-pla (fish sauce) is a clear brown liquid traditionally produced by fermentation of fish and widely used in Southeast Asia and, to some extent, in some other parts of the world (Saisithi et al., 1966; Beddows, 1998). A related product, bu-du (Muslim sauce or fish sauce), is a viscous brown liquid with grey colloidal fish separated from the fish bones suspended in it, and it has a salty taste (Phithakpol et al., 1995). These products are rich in various nutrients, particularly amino acids and peptides, and contain a high concentration of $\mathrm{NaCl}$, which allow various halophilic micro-organisms to thrive (Lopetcharat et al., 2001; Tanasupawat \& Komagata, 2001). Nevertheless, only a

Published online ahead of print on 27 August 2004 as DOI 10.1099/ ijs.0.63272-0.

The GenBank/EMBL/DDBJ accession number for the 16S rRNA gene sequence of strain IS40-3 ${ }^{\top}$ is AB127980. few types of bacteria have been isolated from the fish sauce samples and subjected to taxonomic study. In Thailand, Halobacterium salinarum and 'Halobacillus thailandensis' have been isolated from the fish sauce samples: these are extremely halophilic bacteria/archaea that grow optimally at 20-25\% NaCl. Other bacteria isolated were moderately halophilic bacteria that grew optimally at 3-15\% NaCl, such as Tetragenococcus halophilus and Tetragenococcus muriaticus (Chaiyanan et al., 1999; Thongthai et al., 1992; Thongsanit et al., 2002). Recently, we isolated a number of halophilic bacteria/archaea from fish sauce samples to study the microbial diversity of this product. In this report, we consider eight isolates of aerobic, spore-forming, Grampositive, moderately halophilic bacteria by characterizing their phenotypic, chemotaxonomic and phylogenetic properties to elucidate their taxonomic positions.

The halophilic bacteria were isolated from the fish sauce 
samples (nam-pla and bu-du) that were collected from factories and markets in Thailand by the spread-plate technique on agar plates of JCM medium no. 168 [composed of $\left(\mathrm{l}^{-1}\right) 200 \mathrm{~g} \mathrm{NaCl}, 5 \mathrm{~g}$ Casamino acids, $5 \mathrm{~g}$ yeast extract, $1 \mathrm{~g}$ glutamic acid, $2 \mathrm{~g} \mathrm{KCl}, 3 \mathrm{~g}$ trisodium citrate, $20 \mathrm{~g} \mathrm{MgSO}_{4} .7 \mathrm{H}_{2} \mathrm{O}, 36 \mathrm{mg} \mathrm{FeCl}_{2} .4 \mathrm{H}_{2} \mathrm{O}, 0.36 \mathrm{mg}$ $\mathrm{MnCl}_{2} .4 \mathrm{H}_{2} \mathrm{O}, 20 \mathrm{~g}$ agar; $\left.\mathrm{pH} 7 \cdot 2\right]$ incubated at $37^{\circ} \mathrm{C}$ for 1-2 weeks. The isolates were routinely cultivated in modified JCM medium no. 168, in which the $\mathrm{NaCl}$ concentration had been reduced to $100 \mathrm{~g} \mathrm{l}^{-1}$ (designated Lentibacillus medium: JCM medium no. 377). Lentibacillus salicampi JCM $11462^{\mathrm{T}}$, which was used as a reference strain, was cultivated in the same way.

Unless otherwise stated, the tested strains were grown in liquid or on agar forms of JCM medium no. 377. Colony and cell morphologies were examined using cells grown on agar plates at $37^{\circ} \mathrm{C}$ for 5 days. The Hucker-Conn modification was used for Gram staining (Hucker \& Conn, 1923). Critical-point-dried cells were observed under a scanning electron microscope. Flagella were observed by transmission electron microscopy of cells shadowed with platinum/ palladium. Methyl red and Voges-Proskauer tests were performed and catalase and oxidase activities, indole production, nitrate reduction and hydrolysis of arginine, starch, tyrosine, tributyrin, Tween 80, xanthine and hypoxanthine were tested for by using the methods of Barrow \& Feltham (1993). The Casamino acids in JCM medium no. 377 were omitted from the medium used to test for the hydrolysis of gelatin and casein. Urease was detected on Christensen's medium (Barrow \& Feltham, 1993) supplemented with $10 \%(\mathrm{w} / \mathrm{v}) \mathrm{NaCl}$. Acid production from carbohydrate was determined in the medium described by Leifson (1963) supplemented with $6.5 \%(\mathrm{w} / \mathrm{v})$ $\mathrm{NaCl}$. Growth under anaerobic conditions on agar plates with or without nitrate $(1 \%, \mathrm{w} / \mathrm{v})$ was investigated using a Gaspak (BBL) anaerobic jar. Growth at various temperatures $\left(5-60^{\circ} \mathrm{C}\right)$ was examined using a temperature-gradient incubator (model TN-3; Advantec). $\mathrm{NaCl}$ requirements were determined in medium containing various $\mathrm{NaCl}$ concentrations $(0-30 \%, w / v)$. At lower $\mathrm{NaCl}$ concentrations $(0-2 \cdot 0 \%, \mathrm{w} / \mathrm{v}), \mathrm{MgSO}_{4} \cdot 7 \mathrm{H}_{2} \mathrm{O}$ was omitted from the test medium, while $\mathrm{KCl}$ and $\mathrm{C}_{6} \mathrm{H}_{5} \mathrm{Na}_{3} \mathrm{O}_{7} \cdot 2 \mathrm{H}_{2} \mathrm{O}$ (tri-sodium citrate dihydrate) were added. Growth was monitored by measuring culture turbidity at $660 \mathrm{~nm}$.

meso-Diaminopimelic acid, in the peptidoglycan, and menaquinones were analysed as described previously (Komagata \& Suzuki, 1987). Polar lipids were determined according to the method of Minnikin et al. (1984). Quantitative analysis of cellular fatty acids was performed with the Microbial Identification System (MIDI). DNAs were isolated and purified according to the method of Saito \& Miura (1963). The DNA G + C content was determined by the method of Tamaoka \& Komagata (1984), using reversed-phase HPLC. DNA-DNA hybridization was conducted as reported previously (Ezaki et al., 1989) and detected by the colorimetric method (Tanasupawat et al., 2000). The 16S rRNA gene fragments were PCR-amplified with primers EB-20F (5'-AGTTTGATCCTGGCTC-3', positions 10-25 according to the Escherichia coli numbering system) and EB-1530R (5'-AAGGAGGTGATCCAGCC-3', positions 1541-1525). The 16S rRNA gene fragment was separated by agarose gel electrophoresis and recovered by using the GenElute Minus EtBr spin column (Sigma). The sequence was determined using the BigDye Terminator Cycle Sequencing Ready Reaction kit (version 3.0; Applied Biosystems) in an ABI PRISM 310 genetic analyser (Applied Biosystems) with the following primers: EB-10F and EB520R (5'-ACCGCGGCTGCTGGC-3', positions 531-516), EB-530F (5'-GTGCCAGCAGCCGCGG-3', positions 515530), EB-1100R (5'-AGGGTTGCGCTCGTTG-3', positions 1115-1100), EB-1110F (5'-GCAACGAGCGCAACCC-3', positions 1099-1114) and EB-1530R. The sequence was multiply aligned with the CLUSTAL W program (version 1.81; Thompson et al., 1994), then the alignment was manually

Table 1. Strain designations, sources, DNA G+C content and DNA-DNA relatedness among the isolates and $L$. salicampi JCM $11462^{\top}$

\begin{tabular}{|c|c|c|c|c|c|}
\hline \multirow[t]{2}{*}{ Strain } & \multirow[t]{2}{*}{ Source } & \multirow{2}{*}{$\begin{array}{c}\mathrm{G}+\mathrm{C} \\
\text { content }(\mathrm{mol} \%)\end{array}$} & \multicolumn{3}{|c|}{ DNA-DNA similarity with labelled strain (\%): } \\
\hline & & & JCM $11462^{\mathrm{T}}$ & IS40-3 ${ }^{\mathrm{T}}$ & PS9-2 \\
\hline \multicolumn{6}{|l|}{ Group I } \\
\hline BN2-2 (= PCU 226) & Bu-du & $42 \cdot 5$ & 96 & 1 & 12 \\
\hline DB8-4 (= =PCU 227) & Nam-pla & $42 \cdot 3$ & 71 & 1 & 19 \\
\hline KS333-3B (=JCM $12151=$ PCU $228=$ TISTR 1536 $)$ & Nam-pla & $42 \cdot 5$ & 102 & 14 & 8 \\
\hline \multicolumn{6}{|l|}{ Group II } \\
\hline IS40-3 ${ }^{\mathrm{T}}\left(=\mathrm{JCM} 12147^{\mathrm{T}}=\right.$ PCU $229^{\mathrm{T}}=$ TISTR $\left.1535^{\mathrm{T}}\right)$ & Nam-pla & $43 \cdot 4$ & 12 & 100 & 113 \\
\hline IS40-2 (= PCU 230) & Nam-pla & $43 \cdot 5$ & 32 & 98 & 111 \\
\hline IS10-5 (= PCU 231) & Nam-pla & $43 \cdot 3$ & 27 & 96 & 118 \\
\hline IO-1 ( = PCU 232) & Nam-pla & $43 \cdot 2$ & 13 & 82 & 85 \\
\hline PS9-2 $(=$ JCM $12148=$ PCU 233 $)$ & Nam-pla & $43 \cdot 3$ & 14 & 79 & 100 \\
\hline L. salicampi JCM $11462^{\mathrm{T}}$ & Salt field & $42 \cdot 4$ & 100 & 13 & 11 \\
\hline
\end{tabular}


Table 2. Phenotypic characteristics of the Group I and Group II isolates

Taxa are identified as L. salicampi for Group I and L. juripiscarius sp. nov. for Group II. All strains grew at pH 5-9, produced terminal spores, showed catalase and oxidase activities, reduced nitrate, hydrolysed casein, gelatin and Tween 80, and produced acid from D-fructose, D-glucose, glycerol, D-ribose and D-xylose. They showed negative reactions for urease, in the Voges-Proskauer reaction, for $\mathrm{H}_{2} \mathrm{~S}$ formation, in the methyl red test, for indole formation and for hydrolysis of arginine, starch, tyrosine, tributyrin, phenylalanine, hypoxanthine and xanthine. Anaerobic growth was observed in medium containing nitrate.

\begin{tabular}{|c|c|c|c|c|}
\hline Characteristic & $\mathrm{JCM} 11462^{\mathrm{T}}$ & Group I (3 strains) & IS $40-3^{T}$ & Group II (5 strains) \\
\hline Chains of cells & - & - & + & + \\
\hline Colony size (mm, diameter) & $0 \cdot 2-1 \cdot 3$ & $0 \cdot 2-1 \cdot 3$ & $1 \cdot 3-3 \cdot 2$ & $0 \cdot 9-3 \cdot 9$ \\
\hline Temperature range $\left({ }^{\circ} \mathrm{C}\right)$ & $10-40$ & $10-40$ & $10-45$ & $10-45$ \\
\hline $\mathrm{NaCl}$ range $(\%)$ & $3-25$ & $3-25$ & $3-30$ & $3-30$ \\
\hline Cellobiose & $\mathrm{W}$ & + & - & - \\
\hline D-Galactose & $\mathrm{w}$ & + & - & - \\
\hline D-Mannose & $\mathrm{W}$ & + & - & - \\
\hline Salicin & $\mathrm{w}$ & $\mathrm{W}(2)^{*}$ & - & - \\
\hline Sucrose & - & - & $\mathrm{w}$ & $\mathrm{W}(4)^{\star}$ \\
\hline
\end{tabular}

${ }^{\star}$ The numbers of weakly positive strains are shown in parentheses.

verified and edited prior to the construction of a phylogenetic tree. The phylogenetic tree was constructed by the neighbour-joining method (Saitou \& Nei, 1987) in MEGA program version 2.1 (Kumar et al., 2001). The confidence values of branches of the phylogenetic tree were determined using bootstrap analyses (Felsenstein, 1985) based on 1000 resamplings.

Eight aerobic, spore-forming, Gram-positive, moderately halophilic rods were isolated from the fish sauce samples, as shown in Table 1. These isolates were divided into two groups, Group I and Group II, according to their morphological, cultural, physiological and biochemical characteristics and their DNA-DNA similarities, as shown in Tables 1 and 2.

The cells of the isolates were rod-shaped, measuring approximately $0 \cdot 4-0 \cdot 5 \times 2-6 \mu \mathrm{m}$ (for Group I) or $0 \cdot 4-$ $0 \cdot 5 \times 1 \cdot 5-6 \mu \mathrm{m}$ (for Group II). The Group I isolates and L. salicampi JCM $11462^{\mathrm{T}}$ occurred singly, in pairs or in short chains, whereas the Group II isolates tended to form crooked chains comprising several cells. Oval spores lay terminally in swollen sporangia (Fig. 1). They grew optimally in the presence of $10-15 \% \mathrm{NaCl}$, at $30-39^{\circ} \mathrm{C}$ and approximately $\mathrm{pH}$ 7. Other morphological, cultural, physiological and biochemical properties are shown in Table 2. The properties of L. salicampi JCM $11462^{\mathrm{T}}$ determined by us were basically in agreement with those reported by Yoon et al. (2002), except for acid production from carbohydrates. In our analysis, the type strain of $L$. salicampi (JCM $11462^{\mathrm{T}}$ ) produced acid from cellobiose (weak), D-fructose, D-galactose (weak), D-glucose, Dmannose (weak), D-ribose and xylose (sometimes weak); according to Yoon et al. (2002), strain SF- $20^{\mathrm{T}}$ (=JCM $11462^{\mathrm{T}}$ ) does not produce acid from any of these sugars. The reason for the discrepancy is not clear, and our results were reproducible.

All strains, including L. salicampi JCM $11462^{\mathrm{T}}$, contained meso-diaminopimelic acid as a diagnostic diamino acid, as well as glutamic acid and alanine in the cell-wall peptidoglycan. The predominant isoprenoid quinone found was MK-7. Polar lipid analysis revealed the presence of phosphatidylglycerol, diphosphatidylglycerol and an unidentified glycolipid. The cellular fatty acid profiles for all strains

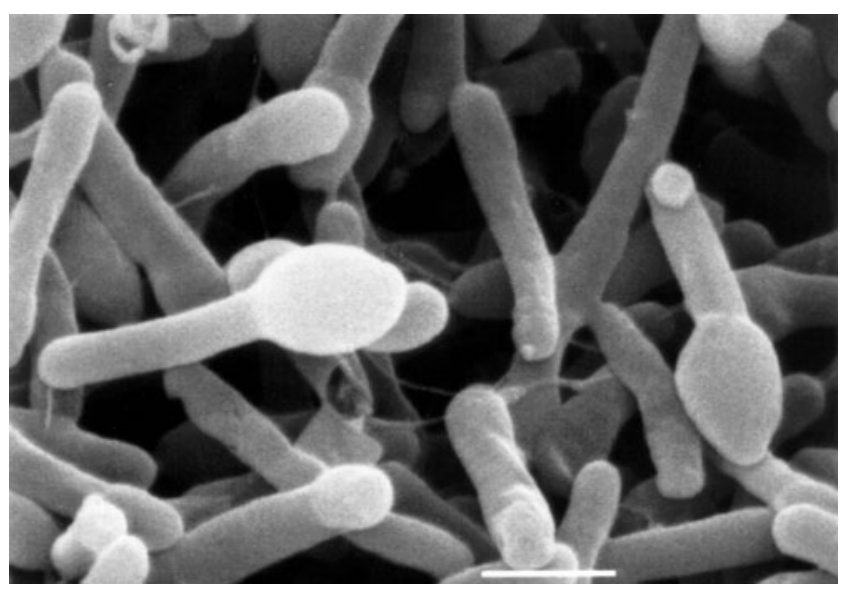

Fig. 1. Scanning electron micrograph of strain $I S 40-3^{\top}$ grown in Lentibacillus medium at $37^{\circ} \mathrm{C}$. Bar, $1 \mu \mathrm{m}$. 
tested contained the following components (\%): anteiso$\mathrm{C}_{15: 0}(38-54)$, iso- $\mathrm{C}_{16: 0}(13-30)$, anteiso- $\mathrm{C}_{17: 0}$ (13-18), iso- $\mathrm{C}_{15: 0}(3-18)$ and iso- $\mathrm{C}_{14: 0}(5-13)$. The $\mathrm{G}+\mathrm{C}$ contents of the DNAs of Group I and Group II were $42 \cdot 2-42 \cdot 5$ and $43 \cdot 2-43 \cdot 5 \mathrm{~mol} \%$, respectively, whereas that for L. salicampi JCM $11462^{\mathrm{T}}$ was $42 \cdot 4 \mathrm{~mol} \%$. As shown in Table $1, L$. salicampi JCM $11462^{\mathrm{T}}$ showed high levels of DNA-DNA similarity to the Group I isolates (96-102\%). Also, high DNA-DNA similarity values were detected between the Group II strains (85-118\%); however, the values between the Group II and Group I strains (or L. salicampi JCM $\left.11462^{\mathrm{T}}\right)$ were significantly low $(<32 \%)$.
Almost-complete 16S rRNA gene sequences of strain IS40-3 $3^{\mathrm{T}}$, used to represent Group II, determined in this study contained 1524 nucleotide positions, and the phylogenetic analysis was conducted with sequences of representative strains of the family Bacillaceae and related taxa. Ambiguous and unalignable bases were eliminated, leaving 1233 positions for comparison in the phylogenetic analysis. The analysis revealed that strain IS40-3 $3^{\mathrm{T}}$ was part of a coherent cluster that included the genera Lentibacillus and Virgibacillus, as shown in Fig. 2. In this cluster, the close relationship between strain IS40-3 $3^{\mathrm{T}}$ and $L$. salicampi was supported by high $16 \mathrm{~S}$ rRNA gene sequence similarity

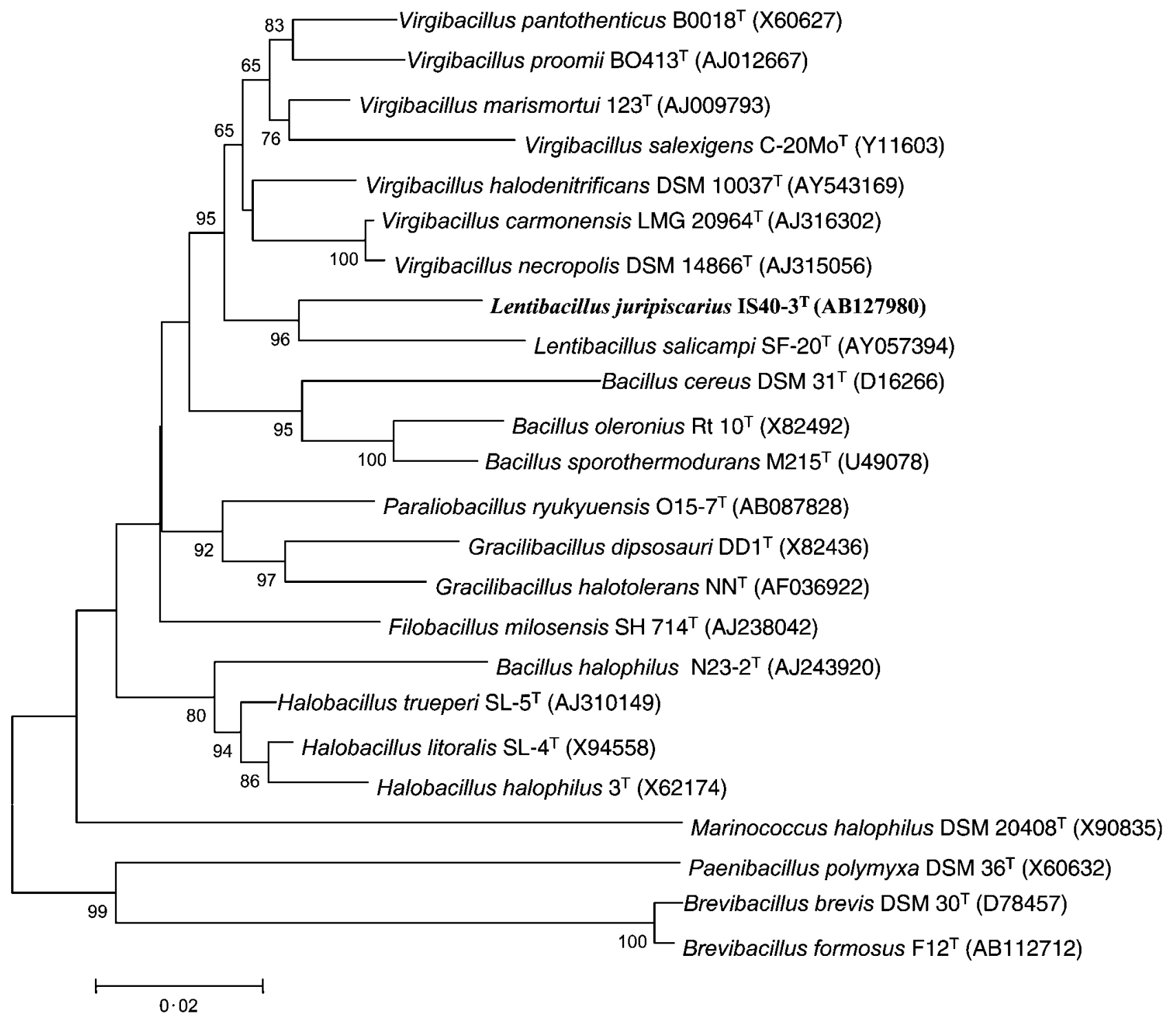

Fig. 2. Phylogenetic tree showing the relationships between $L$. juripiscarius $I S 40-3^{\top}$ and related bacterial species, based on $16 \mathrm{~S}$ rRNA gene sequences. The branching pattern was generated by the neighbour-joining method. Bootstrap percentages above $60 \%$, based on 1000 replications, are shown at the nodes. Bar, 2 substitutions per 100 nucleotide positions. 
$(95 \cdot 2 \%)$ and a high bootstrap value $(96 \%)$. Strain IS40-3 $3^{\mathrm{T}}$ showed $93 \cdot 3-95 \cdot 6 \% 16 \mathrm{~S}$ rRNA gene sequence similarity to members of the genus Virgibacillus, and less than $94 \cdot 2 \%$ to other members of the family Bacillaceae.

Our novel isolates were aerobic, spore-forming, Grampositive, rod-shaped, moderately halophilic bacteria. Bacteria with such characteristics are commonly observed in salty environments such as salterns, salted soils, soda lakes and salted foods (including fish sauce); however, they constitute a phylogenetically heterogeneous group of micro-organisms, represented by Halobacillus (Spring et al., 1996), Virgibacillus (Heyndrickx et al., 1998), Gracilibacillus (Wainø et al., 1999), Filobacillus (Schlesner et al., 2001), Jeotgalibacillus (Yoon et al., 2001), Lentibacillus (Yoon et al., 2002), Paraliobacillus (Ishikawa et al., 2002) and certain Bacillus species. These genera could be differentiated not only by means of phylogenetic distances but also by their chemotaxonomic profiles, including the diamino acid composition of cell walls, cellular fatty acid patterns and DNA G $+\mathrm{C}$ content. Our isolates can be divided into two groups, Group I and Group II, according to their cultural, physiological and biochemical properties and by means of the DNA-DNA hybridization study as described above. Although the 16S rRNA gene sequences of the Group I strains have not been determined, they shared almost identical phenotypic properties with the type strain of $L$. salicampi, the sole member of the genus Lentibacillus. Furthermore, the high DNA-DNA similarities with $L$. salicampi JCM $11462^{\mathrm{T}}$ warrant the inclusion of Group I strains in L. salicampi. On the other hand, the representative strain of Group II, IS40-3 $3^{\mathrm{T}}$, is most closely affiliated to $L$. salicampi on the basis of $16 \mathrm{~S}$ rRNA gene sequence comparisons, indicating that the Group II strains are also members of the genus Lentibacillus. The generic assignment is supported by the fact that their chemotaxonomic profiles (i.e. the presence of meso-diaminopimelic acid as the diagnostic diamino acid in the peptidoglycan, MK-7 as the major menaquinone, anteiso- $\mathrm{C}_{15: 0}$ and iso- $\mathrm{C}_{16: 0}$ as the major cellular fatty acids, and phosphatidylglycerol and diphosphatidylglycerol as the major polar lipids, and the DNA G + C content of $42-43 \mathrm{~mol} \%$ ) correspond with that of the genus Lentibacillus. The genus Virgibacillus now incorporates the former Salibacillus species (Heyrman et al., 2003); however, the genera Lentibacillus and Virgibacillus retain separate phylogenetic status, as shown in Fig. 2. In addition, these two genera can be differentiated on the basis of iso- $\mathrm{C}_{16: 0}$ content (13-30\% for Lentibacillus, 3$8 \%$ for Virgibacillus) and, possibly, on the basis of DNA $\mathrm{G}+\mathrm{C}$ content $(42-43 \%$ for Lentibacillus, $36-41 \%$ for Virgibacillus, except for Virgibacillus marismortui).

As shown in Table 2, Group II strains can be differentiated from $L$. salicampi strains by cell shape, motility, maximum growth temperature and $\mathrm{NaCl}$ concentration requirements, and by the production of acid from sucrose but not from D-mannose, cellobiose or salicin. The DNA-DNA hybridization study supports the view that Group II strains are separate from L. salicampi. In addition, 16S rRNA gene sequence comparison reveals that the representative strain, IS40-3 ${ }^{\mathrm{T}}$, is closely related to L. salicampi; however, the sequence similarity is still too low $(<96 \%)$ to allow inclusion in the same species. Therefore, Group II isolates should be classified as a novel species of the genus Lentibacillus, for which we propose the name Lentibacillus juripiscarius sp. nov.

\section{Description of Lentibacillus juripiscarius sp. nov.}

Lentibacillus juripiscarius (ju.ris.pis'ca.ri.us. L. n. jus juris sauce; L. adj. piscarius - $a$-um of, or belonging to, fish; N.L. masc. adj. juripiscarius of a fish sauce).

Cells are Gram-positive, rod-shaped, $0 \cdot 4-0 \cdot 5 \times 1 \cdot 5-6 \mu \mathrm{m}$, non-motile, lack flagella, and form crooked chains made up of several cells. Oval endospores form at cell terminal position in swollen sporangia. Colonies are white to cream and are $0.9-3.9 \mathrm{~mm}$ in diameter after 5 days on Lentibacillus agar medium. Grows aerobically, and anaerobically in the presence of nitrate. Grows between 10 and $45^{\circ} \mathrm{C}$ (optimally at $37^{\circ} \mathrm{C}$ ) and between pH 5 and 9 (optimally at $\mathrm{pH} 7 \cdot 0$ ). Requires $3-30 \% \mathrm{NaCl}$ (optimally, $10 \% \mathrm{NaCl}$ ) for growth. Catalase- and oxidase-positive but ureasenegative. Reduces nitrate. Hydrolyses casein, Tween 80 and gelatin, but not arginine, starch, tyrosine, tributyrin, phenylalanine, xanthine or hypoxanthine. Produces acid from D-fructose, D-glucose, glycerol, D-ribose, sucrose and D-xylose, but not from amygdalin, L-arabinose, cellobiose, D-galactose, inulin, lactose, maltose, mannitol, D-mannose, melibiose, melezitose, methyl $\alpha$-D-glucoside, myo-inositol, raffinose, rhamnose, salicin, sorbitol or trehalose. Peptidoglycan contains meso-diaminopimelic acid. Predominant menaquinone is MK-7. Fatty acid profile is largely composed of anteiso- $\mathrm{C}_{15: 0}$ and iso- $\mathrm{C}_{16: 0}$. Predominant polar lipids are phosphatidylglycerol, diphosphatidylglycerol and an unidentified glycolipid. The DNA $\mathrm{G}+\mathrm{C}$ content is $43 \mathrm{~mol} \%$.

The type strain, IS40-3 $3^{\mathrm{T}}\left(=\mathrm{JCM} 12147^{\mathrm{T}}=\mathrm{PCU} 229^{\mathrm{T}}=\right.$ TISTR $\left.1535^{\mathrm{T}}\right)$, was isolated from sauce produced in Thailand by the fermentation of fish.

\section{Acknowledgements}

This study was supported by the Thailand Research Fund for a 2001 Royal Golden Jubilee Scholarship as a research grant to S.N., and, in part, by Rachadapiseksompoj Research Grant, Chulalongkorn University (2002).

\section{References}

Barrow, G. I. \& Feltham, R. K. A. (1993). Cowan and Steel's Manual for the Identification of Medical Bacteria, 3rd edn. Cambridge: Cambridge University Press.

Beddows, C. G. (1998). Fermented fish and fish products. In Microbiology of Fermented Food, 3rd edn, vol. 1, pp. 416-429. Edited by B. J. B. Wood. New York: Blackie. 
Chaiyanan, S., Chaiyanan, S., Maugel, T., Huq, A., Robb, F. T. \& Colwell, R. R. (1999). Polyphasic taxonomy of a novel Halobacillus, Halobacillus thailandensis sp. nov. isolated from fish sauce. Syst Appl Microbiol 22, 360-365.

Ezaki, T., Hashimoto, Y. \& Yabuuchi, E. (1989). Fluorometric deoxyribonucleic acid-deoxyribonucleic acid hybridization in microdilution wells as an alternative to membrane filter hybridization in which radioisotopes are used to determine genetic relatedness among bacterial strains. Int J Syst Bacteriol 39, 224-229.

Felsenstein, J. (1985). Confidence limits on phylogenies: an approach using the bootstrap. Evolution 39, 783-791.

Heyndrickx, M., Lebbe, L., Kerster, K., De Vos, P., Forsyth, G. \& Logan, N. A. (1998). Virgibacillus: a new genus to accommodate Bacillus pantothenticus (Proom and Knight 1950). Emended description of Virgibacillus pantothenticus. Int J Syst Bacteriol 48, 99-106.

Heyrman, J., Logan, N. A., Busse, H.-J., Balcaen, A., Lebbe, L., Rodriguez-Diaz, M., Swings, J. \& De Vos, P. (2003). Virgibacillus carmonensis sp. nov., Virgibacillus necropolis sp. nov. and Virgibacillus picturae sp. nov., three novel species isolated from deteriorated mural paintings, transfer of the species of the genus Salibacillus to Virgibacillus, as Virgibacillus marismortui comb. nov. and Virgibacillus salexigens comb. nov., and emended description of the genus Virgibacillus. Int J Syst Evol Microbiol 53, 501-511.

Hucker, G. J. \& Conn, H. J. (1923). Method of Gram staining. Tech Bull N Y St Agric Exp Sta 93, 3-37.

Ishikawa, M., Ishizaki, S., Yamamoto, Y. \& Yamasato, K. (2002). Paraliobacillus ryukyuensis gen. nov., sp. nov., a new Gram-positive, slightly halophilic, extremely halotolerant, facultative anaerobe isolated from a decomposing marine alga. J Gen Appl Microbiol 48, 269-279.

Komagata, K. \& Suzuki, K.-I. (1987). Lipids and cell-wall analysis in bacterial systematics. Methods Microbiol 19, 161-203.

Kumar, S., Tamura, K., Jakobson, I. B. \& Nei, M. (2001). MEGA2: molecular evolution analysis software. Bioinformatics 17, 1244-1245. Leifson, E. (1963). Determination of carbohydrate metabolism of marine bacteria. J Bacteriol 85, 1183-1184.

Lopetcharat, K., Choi, Y. J., Park, J. W. \& Daeschel, M. A. (2001). Fish sauce products and manufacturing: a review. Food Rev Int 17, $65-88$.

Minnikin, D. E., O'Donnell, A. G., Goodfellow, M., Alderson, G., Athalye, M., Schaal, A. \& Parlett, J. H. (1984). An integrated procedure for the extraction of bacterial isoprenoid quinones and polar lipid. J Microbiol Methods 2, 233-241.

Phithakpol, B., Varanyanond, W., Reungmaneepaitoon, S. \& Wood, H. (1995). The Traditional Fermented Foods of Thailand. Kuala Lumpur: ASEAN Food Handling Bureau Level 3.

Saisithi, P., Kasemsarn, B., Liston, J. J. \& Dollar, A. M. (1966). Microbiology and chemistry of fermented fish. J Food Sci 31, 105-110.

Saito, H. \& Miura, K. I. (1963). Preparation of transforming deoxyribonucleic acid by phenol treatment. Biochim Biophys Acta 72, 619-629.
Saitou, N. \& Nei, M. (1987). The neighbor-joining method: a new method for reconstructing phylogenetic trees. Mol Biol Evol 4, 406-425.

Schlesner, H., Lawson, P. A., Collins, M. D., Weiss, N., Wehmeyer, U., Völker, H. \& Thomm, M. (2001). Filobacillus milensis gen. nov., sp. nov., a new halophilic spore-forming bacterium with Orn-D-Glu-type peptidoglycan. Int J Syst Evol Microbiol 51, 425-431.

Spring, S., Ludwig, W., Marquez, M. C., Ventosa, A. \& Schleifer, K.-H. (1996). Halobacillus gen. nov., with description of Halobacillus litoralis sp. nov. and Halobacillus trueperi sp. nov., and transfer of Sporosarcina halophila to Halobacillus halophilus comb. nov. Int J Syst Bacteriol 46, 492-496.

Tamaoka, J. S. \& Komagata, K. (1984). Determination of DNA base composition by reverse-phase high-performance liquid chromatography. FEMS Microbiol Lett 25, 125-128.

Tanasupawat, S. \& Komagata, K. (2001). Lactic acid bacteria in fermented foods in Southeast Asia. In Microbial Diversity in Asia. Technology and Prospects, pp. 43-59. Edited by B. H. Nga, H. M. Tan \& K. Suzuki. Singapore: World Scientific Publishing.

Tanasupawat, S., Shida, O., Okada, S. \& Komagata, K. (2000). Lactobacillus acidipiscis sp. nov. and Weissella thailandensis sp. nov., isolated from fermented fish in Thailand. Int J Syst Evol Microbiol 50, 1479-1485

Thompson, J. D., Higgins, D. G. \& Gibson, T. J. (1994). CLUSTAL W: improving the sensitivity of progressive multiple sequence alignment through sequence weighting, position-specific gap penalties and weight matrix choice. Nucleic Acids Res 22, 4673-4680.

Thongsanit, J., Tanasupawat, S., Keeratipibul, S. \& Jatikavanich, S. (2002). Characteristics and identification of Tetragenococcus halophilus and Tetragenococcus muriaticus strains from fish sauce (nampla). Jpn J Lactic Acid Bacteria 13, 46-52.

Thongthai, C., Mcgenity, T. J., Suntinanalert, P. \& Grant, W. D. (1992). Isolation and characterization of an extremely halophilic archaeobacterium from traditionally fermented Thai fish sauce (nam-pla). Lett Appl Microbiol 14, 111-114.

Wainø, M., Tindall, B. J., Schumann, P. \& Ingvorsen, K. (1999). Gracilibacillus gen. nov., with description of Gracilibacillus halotolerans gen. nov., sp. nov.; transfer of Bacillus dipsosauri to Gracilibacillus dipsosauri comb. nov., and Bacillus salexigens to the genus Salibacillus gen. nov., as Salibacillus salexigens comb. nov. Int J Syst Bacteriol 49, 821-831.

Yoon, J.-H., Weiss, N., Lee, K.-C., Lee, I.-S., Kang, K. H. \& Park, Y.-H. (2001). Jeotgalibacillus alimentarius gen. nov., sp. nov., a novel bacterium isolated from jeotgal with L-lysine in the cell wall, and reclassification of Bacillus marinus Rüger 1983 as Marinobacillus marinus gen. nov., comb. nov. Int J Syst Evol Microbiol 51, 2087-2093.

Yoon, J.-H., Kang, K. H. \& Park, Y.-H. (2002). Lentibacillus salicampi gen. nov., sp. nov., a moderately halophilic bacterium isolated from a salt field in Korea. Int J Syst Evol Microbiol 52, 2043-2048. 